SYSTEMS DEVELOPMENT AND TEST CENTER ACTIVITIES IN THE

WIND SYSTEMS PROGRAM AT ROCKY FLATS

\author{
R. L. Moment \\ Rockwell International \\ Golden, Colorado 80401
}

\title{
Introduction
}

\section{$\sqrt{ }$}

In May of 1976, the Energy Research and Development Administration (ERDA) announced award of a contract to Rockwell International, Rocky Flats Plant for providing "Technical and Management Support for the Development of Wind Systems for Farm and Rural Use". The overall objective of this program is to stimulate manufacture of Small Wind Energy Conversion Systems (SWECS) by the private sector and utilization of these systems by the public. Two areas of prime concern are (1) reducing the cost of wind energy, both for the system hardware and the energy produced over the SWECS lifetime and (2) improving the reliability of Wind Turbine Generators (WTGs). Reliability improvements are particularly significant for applications in remote areas where maintenance is extremely difficult and costly.

To meet the overall objectives of this program two major areas of effort are planned. The first one is to establish and operate a national wind Systems Test Center where SWECS would be tested, thereby helping to establish the current state of the technology and to evaluate technology improvements. Funding necessary research and development to advance the technology and assist evolution of more economical and reliable SWECS is the second major activity. This paper summarizes activities in both the areas of test center establishment and funding of technology development programs.

\section{Test Center Establishment}

Primary test center activities have been establishing the site, installirg towers and WTGs and initiating collection of data. Located on the northwest corner of the Rocky Flats plant site, the test center sits on a large flat plains area. The wind regime provides a large variety of conditions from gentle breezes to hurricane-force wind storms. The stronger winds predominate from one direction, and, therefore, the WTG tower arrangement was laid out as shown in Figure 1 , with the rows oriented normal to that direction. Roadways and general construction have been kept to a minimum, in line with a general policy of preserving the natural state of the area as much as possible.

The first WTG installation at the site was position $2.1 *$ and consisted of a 50-foot (15m) folding tower and the 4.1kW Aerowatt machine, originally installed by NASA at Plumbrook, Ohio. Over a period of two and a half months, it generated power irto a resistor bank, and powered a deep well water pump, while being exposed to winds up to $85 \mathrm{mph}$. Early on the morning of February 23 a blade broke off near its point of attachment to the hub and the resulting rotor inbalance caused sufficieut force on the main body casting to fracture it, allowing the entire machine to fall to the ground. An extensive analysis revealed the presence of an old fatigue crack which developed into the final blade failure over a period of time. Damage to the WTG was extensive, involving about $80 \%$ of the ccmponents, and, therefore, repair is not planned.

*All position numbers are shown in Figure 1 


\section{DISCLAIMER}

This report was prepared as an account of work sponsored by an agency of the United States Government. Neither the United States Government nor any agency Thereof, nor any of their employees, makes any warranty, express or implied, or assumes any legal liability or responsibility for the accuracy, completeness, or usefulness of any information, apparatus, product, or process disclosed, or represents that its use would not infringe privately owned rights. Reference herein to any specific commercial product, process, or service by trade name, trademark, manufacturer, or otherwise does not necessarily constitute or imply its endorsement, recommendation, or favoring by the United States Government or any agency thereof. The views and opinions of authors expressed herein do not necessarily state or reflect those of the United States Government or any agency thereof. 


\section{DISCLAIMER}

Portions of this document may be illegible in electronic image products. Images are produced from the best available original document. 
Additional machines and towers erected during the year include:

Position

Tower

WTG

1.1

1.2

1.3

1.4

1.5

1.6

2.2

2.3

2.4

2.5

2.6

WCT 1
Dunlite 40 foot $(12 \mathrm{~m})$

Aermotor 40 foot (12.m)

Octahedral 40 foct (12m)

Concrete pole 40 foot (12m)

Rohn guyed 40 foot (12m)

Wood pole 40 foot $(12 \mathrm{~m})$

Concrete pole 55 foot (17m)

Rohn truss 55 foot (17m)

Rohn guyed 55 foot. (17m)

Steel post 55 foot (17m).

Rohn truss 55 foot (17m)

Meteorological
Dunlite $2 \mathrm{~kW}$

\begin{tabular}{l} 
Kedco $1.2 \mathrm{~kW}$ \\
\hline Sencenbaugh $1 \mathrm{~kW}$ \\
\hline Grumman $15 \mathrm{~kW}$ \\
Zephyr $15 \mathrm{~kW}$ \\
Elektro $6 \mathrm{~kW}$ \\
\hline Jacobs $3 \mathrm{~kW}$ \\
Zephyr Tetrahelix
\end{tabular}

Operation experience with these machines has been of varying duration. No Installation has been entirely trouble free, with problems ranging from cracks in tail vanes to loss of blades. As a direct result of test center experience at Rocky Flats, two manufacturers have redesigned portions of their WTG systems, and one has issued a letter outlining recommended corrections to machines in the field. One other manufacturer has made modifications to its machine based on input from Rocky Flats as well as from other owners. Therefore, it is felt that the test center experiences have had a positive effect on the industry, with the result being improved hardware.

Additional machines on order include:

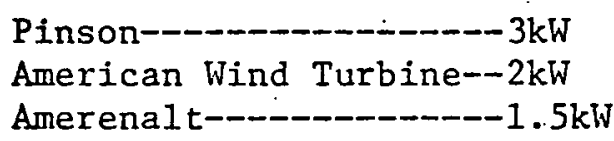

These will be installed on currently vacant towers during the next few months. Some machines are being instrumented with strain gauges, tachometers, yaw transducers, and other equipment necessary for intensive testing data collection prior to placing them on the towers. Others are being equipped with only tachometers and yaw direction indicators. Additional transducers will be installed in the future.

Weather data is being taken at 10 and 40 meter heights on two meteorological towers located at positions WCT 1 and WCT 2 in Figure 1 . In addition two 15-meter high portable towers are positioned near the folding tower and a third 15-meter tower is located opposite position 2.4. All these locations provide wind speed and direction data. Temperature data is collected at both the 10 meter and 40 meter heights on meteorological tower WCT 1. Wind speed and direction data is also taken at each WTG tower. The anemometers are located on booms approximately $11 / 2$ to 2 rotor diameters below the WTG hub height, and provide input to the data collection system.

As noted above, a woll has been drilled at the eite to provido water for normal operations as well as a mini irrigation demonstration system. The well pump is used to fill a stock tank from which a 30 gprn at 50 psi pump feeds the irrigation system. Initially, all WTGs in row 2 will be tied in 
to provide power for this demonstration. Wind power, in the form of DC current, will be converted to 480 volt, 3-phase current, required by the pump motors, by a motor-generator system. At present, the final construction work is being completed.

\section{Technology Development}

Under the Technology Development portion of the Rocky Flats Wind Program, outside organizations will be funded to conduct research and development on SWECS. The objective is to improve WTG performance and reliability and reduce wind-generated energy costs.

Three large programs are currently underway to design and build prototypes of WTGs for test at Rocky Flats. A fourth program funds a continuation of the University of Massachusetts Wind Furnace I. This work will be discussed In detail elsewhere during the workshop.

Needs have been identified for low cost SWECS of $8 \mathrm{~kW}$ output for home or farm use. Also, numerous applications exist in deep well irrigation, general farm/ranch applications, and for small isolated communities and Industries for a WTG of $40 \mathrm{~kW}$ output. Low system cost is an important factor in each of these cases. The third major SWECS application foreseen is for a High-Reliability system, developing approximately $1 \mathrm{~kW}$, for very remote locations where the cost of installing and maintaining conventional power systems is high. Some possible applications in this category are communications repeater stations, pipeline galvonic protection, remote seismic monitoring stations, and powering off-shore navigational aids.

Requests for Proposals (RFPs) were published this year on all three programs. Some details of the system specifications are listed in Tables I, II, and III. Evaluation of the proposals was recently completed, and contract negotiations are currently in progress with a number of organizations. Multiple awards are planned with one being. set aside for small business on both the $8 \mathrm{~kW}$ and High Reliability programs. Winning contractors will be announced as awards are made.

The prototypes developed will be tested at the Rocky Flats Test Center along with the other commercially available machines. Towers will be installed in row 3 of the test site (Figure 1) during the next year to accommodate $40 \mathrm{~kW}$ WTGs. Additional towers will be added for the smal.ler machines.

It is hoped that $8 \mathrm{~kW}, 40 \mathrm{~kW}$ and High Reliability WTGs will be developed in these programs that can provide wind-generated power at prices compctitive with conventional fuels. Even if this ultimate goal is not reached using today's fuel costs, valuable information should become available as to problem areas and technology limitations in building low cost SWECS. This information, in turn, will provide guidance to formulating further technology development programs in the future.

Summary

In summary, the first year and a half of the Rocky Flats Wind Program has been a busy one. A test center has been established with 12 machine towers of varying descriptions and eight WTGs erected to date. Additionally, two 
large and three small meteorological towers have been installed as well as a small irrigation system, typical of the type conmonly used throughout the country. Experience with these niachines has revealed a number of operational problems, but has resulted in hardware modifications by manufacturers.

The other main area of effort has been to solicit and evaluate proposals for development of $8 \mathrm{~kW}, 40 \mathrm{~kW}$, and High Relizbility SWECS. Negotiations are currently in progress on contracts, with awards planned to be completed over the next few months.

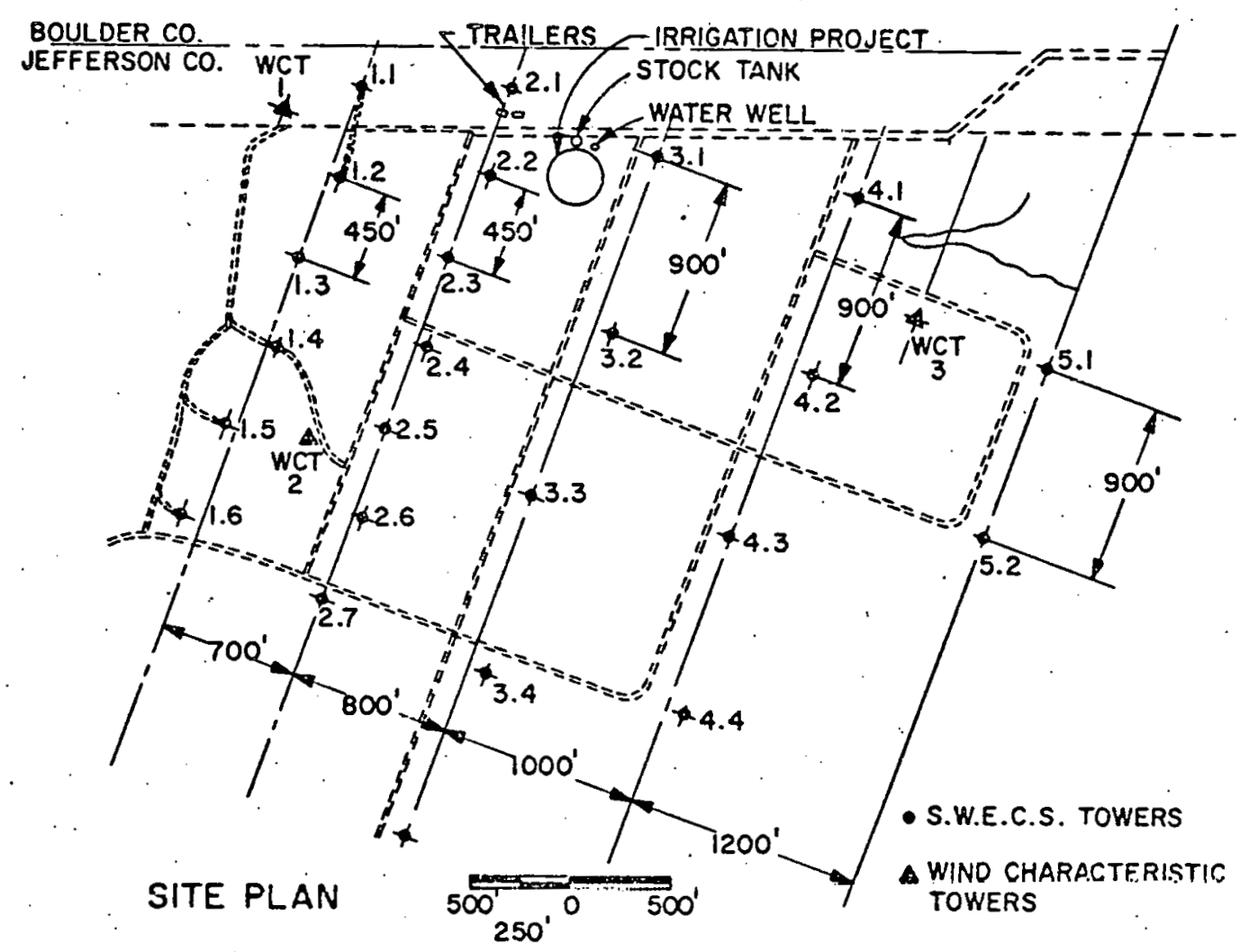

FIGURE I. Layout of the Rocky Flats Wind Systems Test Center 
TABLE I. Design Goals for 3kW WTG System

- OUTPUT - 8 kiV MINIMUM, $6 \cap \mathrm{Hz}, 12 \mathrm{C} / 240 \mathrm{~V}$

- INSTALlation - TIE IN WITH UTILITY OR Gas GENERATIOR INDEPENDENT OF BACK-UP POWER SOURCE

- RATED WIND SPEED - $9 \mathrm{M} / \mathrm{S}$ (20 $\mathrm{mph})$

- CUT-IN WIND SPEED - MINIMIZE

- CUT-OUT WIND SPEED - MAXIMIZE

- SURVIVAL WIND SPEED - $75 \mathrm{M} / \mathrm{S}$ (165 mph)

- SYSTEM LIFE - 25 YEARS MINIMUM

- CAPITAL COST - \$750/kW

- COMPONENTS - ROTOR, TRANSMISSION, GENERATOR, CONTROL MECHANISM, TOWER

- NOT INCLUDED - BATTERIES, INVERTER, OTHER SUCH SECONDARY COMPONENTS, FOUNDATIONS

\section{TABLE II. Design Goals for $40 \mathrm{~kW}$ WTG System}

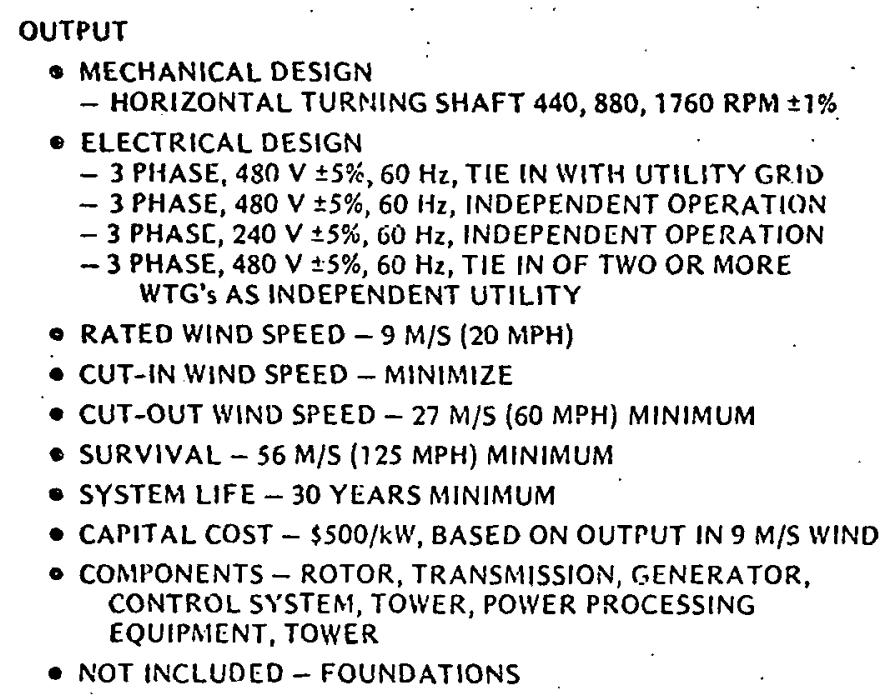

TABLE III. Design Goals for High Reliability WTG System

- OUTPUT - 1 kIV MINIMUN, $120 \mathrm{~V} \pm 15 \mathrm{~V}$ DC WITH

REGULATION FOR CHARGING 120 V EATTERY SYSTEM

- RATED WIND SPEED - 9 M/S (20 MPH)

- CUT-IN WIND SPEED - MINIMUIZE (WITH RFFARD TO POWCR

- CUT-UUI WIND́ SREED - MAXIMIZE $\left\{\begin{array}{l}\text { PRODUCTION AND SYSTEN } \\ \text { COST }\end{array}\right.$

- SURVIVAL WINO SPFFo - $75 \mathrm{M} / \mathrm{S}$ (165 MPH)

- SYSTEM LIFE - 25 YEARS MINIMUM

- RELIABILITY - MEAN TIME BETWEEN FAILURES (MTBR) NO LESS THAN 10 YEARS

- CAPITAL COST - \$ISOO/kW MAXIMUM (BASED ON $9 \mathrm{~m} / \mathrm{S}$ OUTPUT

- COMPONENTS - ROTOR, TRANSMISSION, GENCRATOR, CONTROL SYSTEMS

- NOT INCLUDED - TOWER, FOUNDATION, BATTERIES 